\title{
Peningkatan Minat Belajar Siswa dengan Layanan Bimbingan Kelompok
}

\author{
Evi Soekarno Putri' ${ }^{1}$, Rizal Adicita ${ }^{2}$ \\ STKIP NU TEGAL 1)2 \\ evii.soekarno@gmail.com
}

\begin{abstract}
Abstrak. Siswa kelas VIII B di SMP NU Tegal Semester 2 Tahun Ajaran 2015/2016 menunjukan adanya permasalahan pada sebagian siswa yaitu permasalahan minat belajar yang rendah. Sebagian besar siswa kelas VIII B banyak yang diam, tidak berani, pasif, merasa malu, kurang percaya diri, takut kalau pendapatnya salah, aktivitas siswa dalam mengikuti proses pembelajaran ada yang ramai sendiri, mengantuk, tidak pernah bertanya meskipun belum jelas, sering gelisah jika ada pertanyaan dari guru, sering ijin ke belakang dan sering terlambat. Tujuan penelitian ini adalah meningkatkan minat belajar siswa. Metode yang digunakan menggunakan pendekatan kuantitatif yaitu penelitian tindakan kelas. Responden dalam penelitian ini adalah siswa SMP NU Tegal. Hasil penelitian menunjukkan bahwa bimbingan kelompok meningkatkan minat belajar siswa
\end{abstract}

Kata kunci: Siswa, Minat Belajar, Bimbingan Kelompok 


\section{Pendahuluan}

Manusia pada dasarnya adalah makhluk sosial, dalam kehidupan sehari-hari tidak terlepas dari permasalahan yang pada akhirnya berpusat pada minat belajar selalu minat belajar terlihat jelas dalam suatu karir. Orang yang minat belajar belajarnya tinggi biasanya dalam kehidupan kemasyarakatannya akan mewujudkan karirnya. Untuk mewujudkan karirnya perlu mempersiapkan diri dari dini. Orang yang minat belajar belajarnya tinggi akan nampak pada sikap bejar yang baik, dan tidak menggantungkan diri pada orang lain. Orang yang minat belajar belajarnya tinggi akan mengembangkan cara berfikir yang positif dan memandang karirnya merupakan masa depan dalam hidupnya.

Minat berperan sangat penting dalam kehidupan peserta didik dan mempunyai dampak yang besar terhadap sikap dan perilaku. Siswa yang berminat terhadap kegiatan belajar akan berusaha lebih keras dibandingkan siswa yang kurang berminat. Menurut Slameto (2003) minat adalah kecenderungan yang tetap untuk memperhatikan dan mengenang beberapa kegiatan. Kegiatan yang diminati siswa, diperhatikan terus-menerus yang disertai rasa senang dan diperoleh rasa kepuasan. Lebih lanjut dijelaskan Suryabrata (1988) bahwa minat adalah suatu rasa suka dan ketertarikan pada suatu hal atau aktivitas, tanpa ada yang menyuruh. Minat adalah kecenderungan dalam diri individu untuk tertarik pada sesuatu objek atau menyenangi sesuatu objek. Minat adalah sesuatu pemusatan perhatian yang tidak disengaja yang terlahir dengan penuh kemauannya dan yang tergantung dari bakat dan lingkungan. Dari beberapa pengertian di atas dapat disimpulkan bahwa minat adalah kecenderungan tertarik pada sesuatu yang relatif tetap untuk lebih memperhatikan dan mengingat secara terus-menerus yang diikuti rasa senang untuk memperoleh suatu kepuasan dalam mencapai tujuan pembelajaran.

Dalam belajar diperlukan suatu pemusatan perhatian agar apa yang dipelajari dapat dipahami. Sehingga siswa dapat melakukan sesuatu yang sebelumnya tidak dapat dilakukan. Terjadilah suatu perubahan kelakuan. Perubahan kelakuan ini meliputi seluruh pribadi siswa; baik kognitip, psikomotor maupun afektif. Untuk 
Philanthropy Journal of Psychology

Vol 2 Nomor 2 (2018), 128-144

ISSN 2580-6076 (Print), ISSN 2580-8532 (Online)

meningkatkan minat, maka proses pembelajaran dapat dilakukan dalam bentuk kegiatan siswa bekerja dan mengalami apa yang ada di lingkungan secara berkelompok.

Menurut Nandang (2009) bimbingan kelompok dapat didefinisikan sebagai suatu proses pemberian layanan bantuan kepada individu melalui suasana kelompok yang memungkinkan setiap anggota kelompok untuk belajar berpartisipasi aktif dan berbagi pengalaman dalam upaya mengembangkan wawasan, sikap, dan atau keterampilan yang diperlukan dalam upaya mencegah timbulnya masalah atau dalam upaya pengembangan pribadi.

Masih menurut Nandang (2009) ada beberapa keuntungan yang mendukung diselenggarakannya bimbingan kelompok yaitu (a) bimbingan kelompok lebih bersifat efektif dan efisien, (b) bimbingan kelompok dapat memanfaatkan pengaruhpengaruh seseorang atau beberapa individu terhadap anggota lainnya, (c) dalam bimbingan kelompok terjadi saling tukar pengalaman diantara para anggota kelompok yang dapat berpengaruh terhadap perubahan tingkah laku individu, (d) bimbingan kelompok dapat merupakan awal dari konseling individual, sehingga bimbingan kelompok dapat dimanfaatkan untuk mempersiapkan individu yang akan mendapat layanan konseling, (e) bimbingan kelompok dapat menjadi pelengkap dari teknik individual, dalam arti sebagai layanan tindak lanjut dari konseling individual, (f) bagi kasus-kasus tertentu, bimbingan kelompok dapat digunakan sebagai subtitusi, yakni dilaksanakan karena kasus tidak dapat ditangani dengan teknik lain, (g) dalam bimbingan kelompok terdapat kesempatan menyegarkan watak atau pikiran.

Bimbingan kelompok memiliki sifat yang beragam, mulai dari yang bersifat Informatif sampai pada yang sifatnya teraupetik. Sedangkan dalam praktiknya, bimbingan kelompok dapat dilakukan melalui berbagai teknik seperti diskusi, simulasi, latihan, karyawisata, homeroom program, dan sosiodrama.

Menurut Prayitno (1999) bimbingan kelompok disekolah merupakan kegiatan informasi kepada sekelompok siswa untuk membantu siswa menyusun rencana dan keputusan yang tepat. Pengertian tersebut menekankan pada kegiatan pemberian 
Philanthropy Journal of Psychology

Vol 2 Nomor 2 (2018), 128-144

ISSN 2580-6076 (Print), ISSN 2580-8532 (Online)

informasi dalam suasana kelompok dan adanya penyusunan rencana untuk mengambil keputusan. Dalam bimbingan kelompok memanfaatkan dinamika kelompok untuk mencapai tujuan penyelesaian permasalahan, bimbingan kelompok lebih menekankan suatu upaya bimbingan kepada individu melalui kelompok.

Sedangkan Sukardi (2002) menjelaskan bahwa layanan bimbingan kelompok adalah layanan yang memungkinkan sejumlah peserta didik secara bersama-sama memperoleh bahan dari narasumber tertentu, terutama guru pembimbing atau konselor, yang berguna untuk menunjang kehidupan sehari-hari baik individu sebagai pelajar, anggota keluarga, dan masyarakat serta untuk mempertimbangkan dalam pengambilan keputusan.

Kesuksesan layanan bimbingan kelompok sangat dipengaruhi sejauh mana tujuan yang akan dicapai dalam layanan kelompok yang diselenggarakan. Tujuan bimbingan kelompok yang dikemukakan oleh Prayitno (2004) adalah tujuan umum dan tujuan khusus. Tujuan umum dari layanan bimbingan kelompok adalah berkembangnya sosialisasi siswa, khususnya kemampuan komunikasi anggota kelompok. Sedangkan tujuan khusus bimbingan kelompok bermaksud membahas topik-topik tertentu. Melalui dinamika kelompok yang intensif, pembahasan topiktopik itu mendorong pengembangan perasaan, pikiran, persepsi, wawasan, dan sikap yang menunjang diwujudkannya tingkah laku yang lebih efektif. Dalam hal ini kemampuan komunikasi verbal maupun non verbal ditingkatkan.

Dengan diadakannya bimbingan kelompok ini dapat bermanfaat bagi siswa karena dengan bimbingan kelompok akan timbul interaksi dengan anggota-anggota kelompok mereka memenuhi kebutuhan psikologis, seperti kebutuhan untuk menyesuaikan diri dengan teman-teman sebaya dan diterima oleh mereka, kebutuhan bertukar pikiran dan berbagi perasaan, kebutuhan menemukan nilai-nilai kehidupan sebagai pegangan, dan kebutuhan untuk menjadi lebih mandiri. Prayitno (1999) menjelaskan bahwa dalam penyelenggaraan bimbingan kelompok dikenal dua jenis kelompok, yaitu kelompok bebas dan kelompok tugas. Kelompok bebas adalah dalam kegiatannya para anggota bebas mengemukakan segala pikiran dan 
Philanthropy Journal of Psychology

Vol 2 Nomor 2 (2018), 128-144

ISSN 2580-6076 (Print), ISSN 2580-8532 (Online)

perasaannya dalam kelompok. Selanjutnya apa yang disampaikan mereka dalam kelompok itulah yang menjadi pokok bahasan kelompok. Sedangkan kelompok tugas adalah dalam penyelenggaraan bimbingan kelompok tugas arah dan isi kegiatannya tidak ditentukan oleh para anggota, melainkan diarahkan kepada penyelesaian suatu tugas. Pemimpin kelompok mengemukakan suatu tugas untuk selanjutnya dibahas dan diselesaikan oleh anggota kelompok.

Prayitno (1995) juga mengemukakan bahwa ada tiga komponen penting dalam kelompok yaitu suasana kelompok, anggota kelompok, dan pemimpin kelompok. Suasana kelompok berarti suatu kelompok yang teratur dari dua individu atau lebih yang mempunyai hubungan psikologis secara jelas antara anggota yang satu dengan yang lain Santoso (2004). Dengan kata lain, antar anggota kelompok mempunyai hubungan psikologis yang berlangsung dalam situasi yang dialami secara bersamasama.

Sedangkan menurut Wibowo (2005) mengemukakan suasana atau dinamika kelompok adalah suatu studi yang menggambarkan berbagai kekuatan yang menentukan perilaku anggota dan perilaku kelompok yang menyebabkan terjadinya gerak perubahan dalam kelompok untuk mencapai tujuan bersama sedangkan minat belajar adalah suatu kemampuan umum yang dimiliki siswa untuk mencapai hasil belajar yang optimal yang dapat ditunjukkan dengan kegiatan belajar.

Menurut Slameto (2003) siswa yang berminat dalam belajar mempunyai ciriciri sebagai berikut:: (1) Mempunyai kecenderungan yang tetap untuk untuk memperhatikan dan mengenang sesuatu yang dipelajari secara terus menerus., (2) Ada rasa suka dan senang pada sesuatu yang diminati, (3) memperoleh suatu kebanggaan dan kepuasan pada sesuatu yang diminati. Ada rasa keterikatan pada sesuatu aktivitas-aktivitas yang diminati.,(4) Lebih menyukai suatu hal yang menjadi minatnya daripada yang lainnya. Dimanifestasikan melalui partisipasi pada aktivitas dan kegiatan. Sedangkan yang peneliti maksudkan dengan minat belajar di sini adalah suatu kemampuan umum yang dimiliki siswa untuk mencapai hasil belajar yang optimal yang dapat ditunjukkan dengan kegiatan belajar. 
Philanthropy Journal of Psychology

Vol 2 Nomor 2 (2018), 128-144

ISSN 2580-6076 (Print), ISSN 2580-8532 (Online)

Menurut pengamatan dari peneliti, bahwa siswa kelas VIII B di SMP NU Tegal Semester 2 Tahun Ajaran 2015/2016 menunjukan adanya permasalahan pada sebagian siswa yaitu permasalahan minat belajar yang rendah. Ini semua dapat dilihat dari hasil observasi pada proses pembelajaran di kelas yang dilaksanakan dalam bentuk klasikal ataupun kelompok, jika diberi tugas untuk mengerjakan soal latihan maupun soal ulangan secara individu maupun dalam bentuk kelompok, sebagian besar siswa kelas VIII B banyak yang diam, tidak berani, pasif, merasa malu, kurang percaya diri, takut kalau pendapatnya salah, aktivitas siswa dalam mengikuti proses pembelajaran ada yang ramai sendiri, mengantuk, tidak pernah bertanya meskipun belum jelas, sering gelisah jika ada pertanyaan dari guru, sering ijin ke belakang dan sering terlambat.

Dalam pemberian layanan bimbingan dan konseling di kelas VIII B di SMP NU Tegal Semester 2 Tahun Ajaran 2015/2016 peneliti belum pernah mencoba memanfaatkan fasilitas layanan bimbingan kelompok akibatnya banyak masalah yang muncul di kelas VIII B yang belum dapat terentaskan. Adapun fasilitas yang digunakan dalam pemberian layanan bimbingan dan konseling pada saat ini baru sebatas layanan orientasi, layanan informasi dan layanan penguasaan konten.

Penelitian tindakan kelas ini diharapkan dapat meningkatkan minat belajar siswa yang ada di Kelas VIII B di SMP NU Tegal Semester 2 Tahun Ajaran 2015/2016. Permasalahan ini perlu dientaskan agar siswa minat belajarnya menjadi tinggi, yang pada akhirnya prestasi belajar siswa kelas VIIB dapat meningkat.

Agar permasalahan dalam penelitian ini dapat dipecahkan, maka peneliti mencari solusi yang dirasa paling tepat yaitu dengan memanfaatkan fasilitas layanan bimbingan kelompok dalam melaksanakan tindakan. Menurut peneliti fasilitas tersebut diambil karena dengan memanfaatkan layanan bimbingan kelompok akan dapat meningkatkan minat belajar pada Kelas VIII B di SMP NU Tegal Semester 2 Tahun Ajaran 2015/2016.

Berdasarkan pengamatan peneliti menunjukan ternyata banyak siswa kelas VIII B di SMP NU Tegal Semester 2 Tahun Ajaran 2015/2016 mempunyai minat 
Philanthropy Journal of Psychology

Vol 2 Nomor 2 (2018), 128-144

ISSN 2580-6076 (Print), ISSN 2580-8532 (Online)

belajar rendah. Harapan yang diinginkan dalam penelitian ini adalah siswa kelas VIII B minat belajar siswa meningkat tinggi. Selama melaksanakan layanan bimbingan dan konseling, peneliti belum pernah menggunakan fasilitas layanan bimbingan kelompok dan diharapkan untuk pertemuan selanjutnya peneliti sudah mulai menggunakan fasilitas layanan bimbingan kelompok.

Untuk menindaklanjuti permasalahan tersebut, peneliti perlu mencari solusi yang tepat guna untuk mengatasi masalah minat belajar yang dirasa sangat rendah pada siswa Kelas VIII B di SMP NU Tegal Semester 2 Tahun Ajaran 2015/2016, dengan cara melaksanakan tindakan dengan memanfaatkan fasilitas bimbingan kelompok. Adapun pelaksanaan tindakanya direncanakan dua siklus. Siklus I peneliti menyelenggarakan kegiatan layanan bimbingan kelompok yaitu dengan cara membentuk kelompok dengan beranggotakan 17 siswa. Kegiatan bimbingan kelompok. ini sebagai media untuk mengatasi masalah yang sedang dialami siswa. Adapun topik yang dibahas dalam kegiatan bimbingan kelompok. adalah bagaimana cara meningkatkan minat belajar. Siklus ke II peneliti melanjutkan kegiatan bimbingan konseling dengan memberikan layanan bimbingan kelompok dengan kelompok kecil jumlah anggotanya hanya 6 siswa. Kegiatan bimbingan kelompok. dengan kelompok kecil ini dikandung maksud agar kegiatan dapat lebih efektif dan dinamis.

\section{Metode}

Penelitian tindakan kelas ini dilaksanakan selama 5 bulan yang dimulai dari bulan Desember sampai April 2016 pada semester II Tahun Pelajaran 2015/2016. Kegiatan PTK dimulai pada minggu ke I dan II bulan Desember 2015 peneliti menyusun proposal PTK dan dilanjutkan minggu ke III dan IV bulan Desember 2015 peneliti menyusun instrumen penelitian dan lembar observasi. Sedangkan pada minggu ke II bulan Januari 2016 peneliti membuat rencana tindakan I yang berupa Rencana Pelaksanaan Pelayanan Bimbingan dan Konseling ( RPP BK ). Pada minggu ke III bulan Januari 2016 peneliti mengumpulkan data penelitian melalui pengamatan dengan cara melakukan tindakan yang dilaksanakan pada siklus I. 
Adapun alasan peneliti mengambil data penelitian pada minggu ke III bulan Januari 2016 karena minggu ke III bulan Januari 2016 merupakan hari efektif untuk proses pembelajaran.dan sebelum bulan tersebut peneliti baru mengumpulkan data awal penelitian. Selanjutnya pada minggu ke IV bulan Februari 2016 peneliti melakukan kegiatan evaluasi dan analisis data dari hasil pelaksanaan tindakan pada siklus I. Pada minggu I bulan Maret peneliti melakukan kegiataan refleksi dengan cara membahas dan mendiskusikan hasil tindakan pada siklus I dengan teman sejawat. Untuk selanjutnya pada minggu II bulan Maret 2015 peneliti membuat rencana tindakan II yang merupakan revisi dari hasil pelaksanaan tindakan pada siklus I. Untuk selanjutnya rencana tindakan II tersebut dilaksanakan pada minggu ke III bulan Maret 2015 melalui siklus ke II.

Sedangkan pada minggu ke IV bulan Maret peneliti melakukan kegiatan evaluasi dan analisis data dari hasil tindakan pada siklus II dan pada minggu ke I bulan April 2016 peneliti melakukan kegiatan refleksi melalui pembahasan atau diskusi dengan teman sejawat membahas tentang hasil yang dicapai dalam PTK. Setelah semua kegiatan penelitian sudah selesai dilaksanakan untuk selanjutnya peneliti menyusun laporan penelitian . Penyusunan laporan penelitian dilaksanakan pada minggu 2 dan 3 bulan April 2016.

Penelitian tindakan kelas ini dilaksanakan di kelas VIII B di SMP NU Tegal Semester 2 Tahun Ajaran 2015/2016. Kelas VIII B adalah merupakan salah satu kelas dari 9 kelas yang ada di SMP Negeri I Tegal di Kabupaten Tegal. Kelas VIIIB jumlah siswanya sebanyak 34 siswa yang terdiri dari 18 siswa putra dan 16 putri. Alasan peneliti mengambil tempat penelitian di kelas VIII B di SMP NU Tegal Semester 2 Tahun Ajaran 2015/2016 adalah kelas VIIB merupakan salah satu kelas dari 9 kelas yang siswanya mempunyai minat belajarnya paling rendah dibanding dengan kelas lainnya.

Pada kondisi awal dalam pelaksanaan proses layanan bimbingan dan konseling, peneliti belum memanfaatkan jenis layanan bimbingan kelompok dalam 
upaya mengentaskan minat belajar siswa yang rendah, sehingga dikelas VIII B banyak siswa yang mengalami minat belajar sangat rendah.

Agar permasalahan kesulitan belajar di kelas VIII B dapat segera terentaskan dan minat belajarnya juga dapat meningkat, maka perlu adanya tindakan nyata yang dilakukan peneliti yaitu dengan cara memberikan layanan bimbingan kelompok pada siswa kelas Kelas VIII B di SMP NU Tegal Semester 2 Tahun Ajaran 2015/2016.

Pada siklus I peneliti melakukan tindakan dengan memberikan layanan bimbingan kelompok pada siswa kelas Kelas VIII B di SMP NU Tegal Semester 2 Tahun Ajaran 2015/2016. Pertama membentuk kelompok dengan beranggotakan 17 siswa. Adapun masalah yang diangkat dalam diskusi kelompok adalah masalah minat belajar yang rendah. Dari hasil tindakan yang dilakukan peneliti pada siklus I diharapkan masalah yang dialami siswa yaitu minat belajar siswa dapat meningkat jika dibandingkan dengan kondisi awal sebelum diadakan penelitian.

Pada siklus II peneliti melakukan tindakan terhadap siswa kelas Kelas VIII B di SMP NU Tegal Semester 2 Tahun Ajaran 2015/2016 dengan memberikan layanan bimbingan kelompok dengan kelompok kecil yang beranggotakan sebanyak 6 siswa. Ini dilakukankan agar peneliti dapat lebih fokus pada masalah masing-masing siswa. Dari hasil tindakan yang dilakukan peneliti pada siklus II diharapkan dapat meningkatkan minat belajar siswa agar dapat lebih meningkat jika dibandingkan dengan tindakan pada siklus 1.

Pada kondisi akhir diduga melalui pemberian layanan bimbingan kelompok dapat meningkatkan minat belajar bagi siswa kelas kelas VIII B di SMP NU Tegal Semester 2 Tahun Ajaran 2015/2016.

Secara skematis kerangka berpikir dapat digambarkan melalui bagan berikut : 


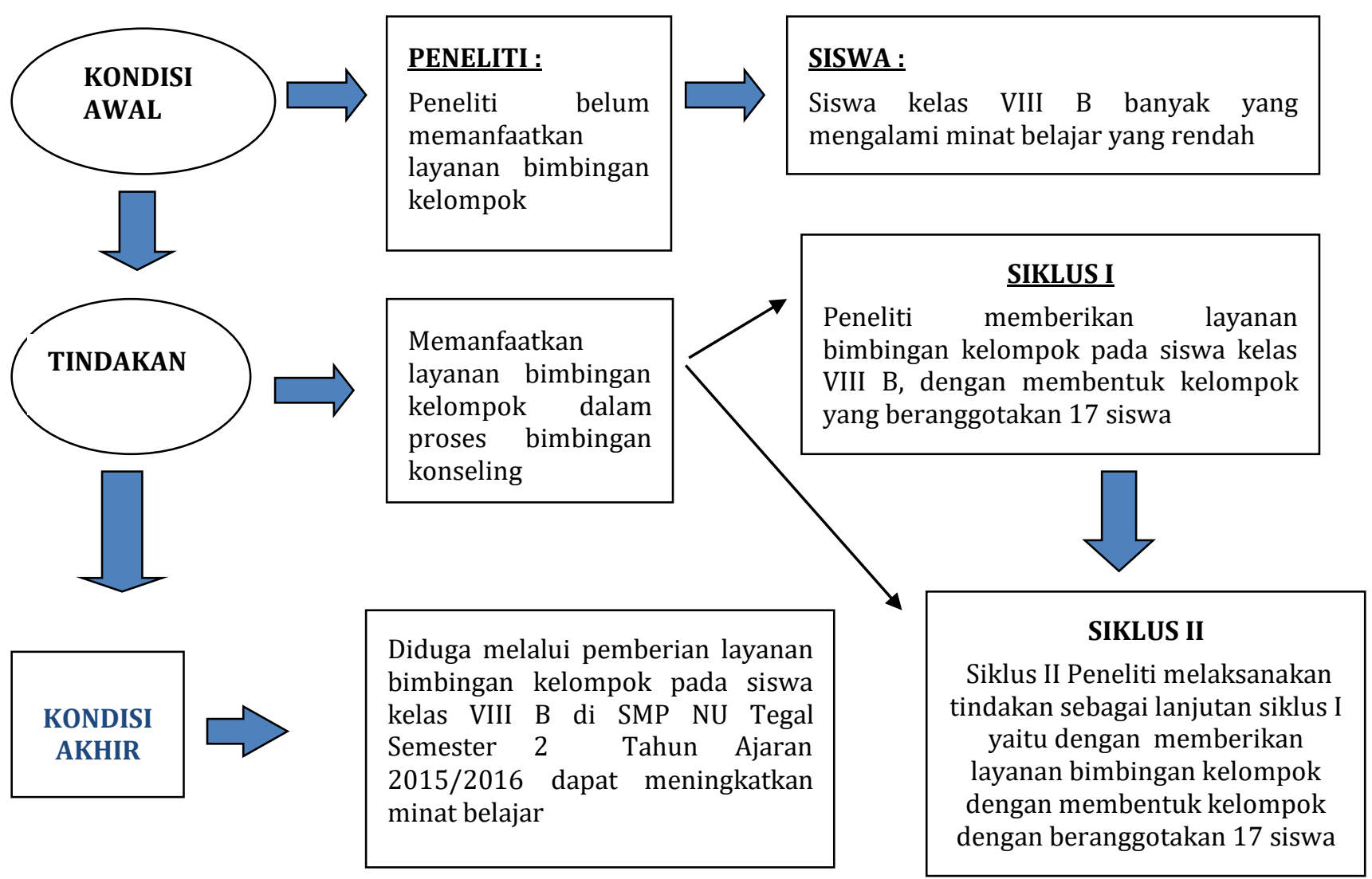

Gambar 1.1

Bagan skema kerangka berpikir

Penelitian ini menggunakan metode penelitian tindakan kelas, yang terdiri dari 2 siklus. Adapun tahapan dari tiap-tiap siklus adalah tahap perencanaan (planning), tahap pelaksanaan tindakan (acting), tahap pengamatan (observating), dan tahap refleksi (reflecting). Keempat tahapan dalam penelitian tindakan kelas yang meliputi perencanaan (planning), tindakan (acting), pengamatan (observating) serta refleksi (reflecting) lebih diperjelas dengan melihat gambar di bawah ini. 


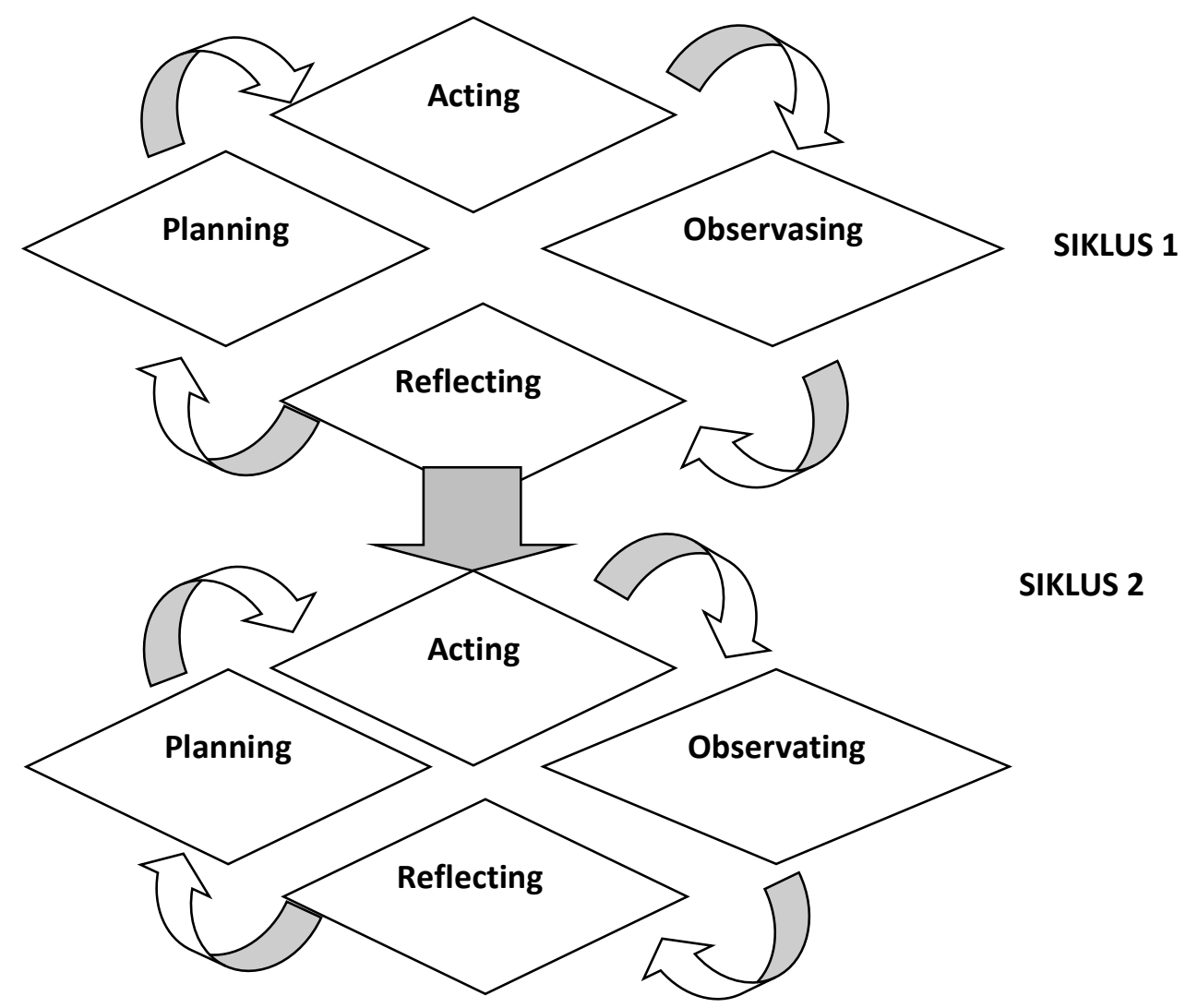

Gambar : 1.2 Gambar Tahapan PTK

Untuk selanjutnya akan peneliti jelaskan dari masing - masing tahapan :

\section{Tahap Perencanaan Tindakan}

Dalam tahap perencanaan tindakan ini peneliti membuat rencana tindakan yang berupa rencana pelaksanaan pelayanan bimbingan dan konseling ( RPP BK ) yang dilaksanakan melalui jenis layanan bimbingan kelompok. Adapun rencana tindakan yang dibuat ini berdasarkan pada hasil observasi terhadap perilaku siswa saat kegiatan pembelajaran yang berkaitan dengan masalah minat belajar yang dialami siswa. Sedangkan topik yang diangkat dalam kegiatan layanan bimbingan kelompok adalah "bagaimana cara mengatasi masalah minat belajar yang rendah". Pelaksanaan tindakan direncanakan 
Philanthropy Journal of Psychology

Vol 2 Nomor 2 (2018), 128-144

ISSN 2580-6076 (Print), ISSN 2580-8532 (Online)

berlangsung selama $2 \times 40$ menit, bertempat di ruang bmbingan kelompok SMP NU Tegal Kabupaten Tegal

\section{Tahap Pelaksanaan Tindakan}

Pada pelaksanaan tindakan, peneliti melaksanakan rencana tindakan yang sudah dibuat yaitu melaksanakan proses layanan bimbingan kelompok terhadap siswa kelas kelas VIII B di SMP NU Tegal Semester 2 Tahun Ajaran 2015/2016 dengan topik bahasan “ bagaimana cara mengatasi minat belajar rendah". Dalam proses kegiatan layanan bimbingan kelompok ini ada 4 tahapan yang harus dilalui yaitu : tahap pembentukan, tahap peralihan, tahap kegiatan dan tahap pengakhiran.

Pada tahap pembentukan ini peneliti membentuk kelompok yang beranggotakan 17 siswa yang berasal dari kelas kelas VIII B di SMP NU Tegal Semester 2 Tahun Ajaran 2015/2016. Setelah kelompok terbentuk selanjutnya dimulai kegiatan. Pertama peneliti yang sebagai pemimpin kelompok membuka kegitan yang dilanjutkan dengan menjelaskan tujuan diadakan layanan bimbingan kelompok dan dilanjutkan pengakraban antar anggota kelompok. Tahap peralihan peneliti menanyakan kepada anggota kelompok tentang kesiapan anggota untuk melanjutkan kegiatan, jika siap maka kegiatan dapat dilanjutkan ke tahap berikutnya.

Tahap kegiatan merupakan kegiatan inti. Adapun kegiatanya sebagai berikut peneliti selaku pemimpin kelompok memberikan topik bahasan yang akan didiskusikan yaitu “ bagaimana cara mengatasi minat belajar rendah“. Selanjutnya anggota mulai berdiskusi mencari solusi untuk mengatasi minat belajar rendah dengan dipandu oleh peneliti.dan setelah diskusi selesai anggota diberi kesempatan untuk menyimpulkan .

Tahap pengakhiran, peneliti mengakhiri kegiatan dengan memberikan pesan agar hasil diskusi dapat dilaksanakan secara sungguh-sungguh sesuai dengan kometmen bersama dan selanjutnya peneliti menutup kegiatan dengan berdo’a bersama.

Pengamatan ini dilakukan untuk mengetahui perkembangan minat belajar yang diindikasikan terjadi pada siswa kelas VIII B di SMP NU Tegal Semester 2 Tahun Ajaran 2015/2016. Adapun alat yang dipergunakan untuk pengamatan ( observasi ) agar didapat hasil yang valid adalah lembar observasi. Lembar observasinya adalah lembar observasi tentang minat belajar siswa. Lembar observasi ini ditujukan terhadap aktivitas siswa dalam mengikuti proses kegiatan layanan bimbingan kelompok yang diantaranya meliputi antusias 
Philanthropy Journal of Psychology

Vol 2 Nomor 2 (2018), 128-144

ISSN 2580-6076 (Print), ISSN 2580-8532 (Online)

siswa dalam mengikuti proses kegiatan layanan bimbingan kelompok, Kesiapan siswa dalam mengikuti kegiatan diskusi, interaksi siswa terhadap anggota kelompok, perhatian siswa terhadap topik bahasan, keberanian siswa dalam mengungkapkan pendapat dalam kegiatan diskusi, usaha siswa dalam memahami pendapat dari anggota kelom[pok , kerjasama dalam kelompok, ketertiban siswa dalam kegiatan diskusi dan kesanggupan siswa dalam menerapkan hasil diskusi. Lembar observasi ini disusun secara sistematis agar observer dapat lebih mudah melakukan pengamatan terhadap aktivitas siswa dan observer juga dapat lebih terfokus pada sasaran.

\section{Hasil}

Menurut pengamatan peneliti, menunjukan bahwa sebagian besar siswa yaitu 22 siswa $(64,70 \%)$ kelas VIII B minat belajarnya sangat rendah, ini juga dapat dilihat dari aktivitas siswa dalam mengikuti proses pembelajaran di kelas ada yang ramai sendiri, mengantuk, tidak pernah bertanya meskipun belum jelas, sering gelisah jika ada pertanyaan dari guru, sering ijin ke belakang dan jiuga sering terlambat.

Dalam pemberian layanan bimbingan dan konseling di kelas VIII B di SMP NU Tegal Semester 2 Tahun Ajaran 2015/2016 peneliti belum pernah mencoba memanfaatkan fasilitas layanan bimbingan kelompok akibatnya banyak masalah yang muncul di kelas VIII B minat belajarnya sangat rendah. Adapun fasilitas yang digunakan dalam pemberian layanan bimbingan dan konseling pada saat ini baru sebatas layanan orientasi, layanan informasi dan layanan penguasaan konten.

Setelah peneliti melaksanakan tindakan pada siklus II dimana peneliti telah menerapkan atau memanfaatkan fasilitas layanan bimbingan kelompok pada siswa kelas VIII B di SMP NU Tegal Semester 2 Tahun Ajaran 2015/2016 Bagaimana cara meningkatkan minat belajar “. Hasilnya sebaga berikut : siswa yang mempunyai minat belajar tinggi pada siklus I berjumlah 20 siswa (58,82 \%) setelah diadakan tindakan pada siklus II terjadi adanya peningkatan yaitu menjadi 27 siswa $(79,41 \%)$. Hal ini dimungkinkan karena peneliti telah menerapkan atau memanfaatkan fasilitas layanan bimbingan kelompok dalam upaya meningkatkan minat belajar siswa kelas kelas VIII B di SMP NU Tegal Semester 2 Tahun Ajaran 2015/2016. Dengan melihat hasil tindakan pada siklus II menurut peneliti karena sudah dapat mencapai indikator penelitian yang ditetapkan dalam penelitian ini yaitu Diharapkan 70 \% dari jumlah siswa kelas VIII B di SMP NU Tegal Semester 2 Tahun Ajaran 
Philanthropy Journal of Psychology

Vol 2 Nomor 2 (2018), 128-144

ISSN 2580-6076 (Print), ISSN 2580-8532 (Online)

2015/2016 minat belajarnya dapat meningkat menjadi tinggi dan sesuai dengan rencana penelitian tindakan kelas ini pelaksanaan tindakan dilaksanakan dua siklus, maka peneliti bersama teman sejawat sebagai kolaborator memutuskan untuk mengakhiri penelitian.

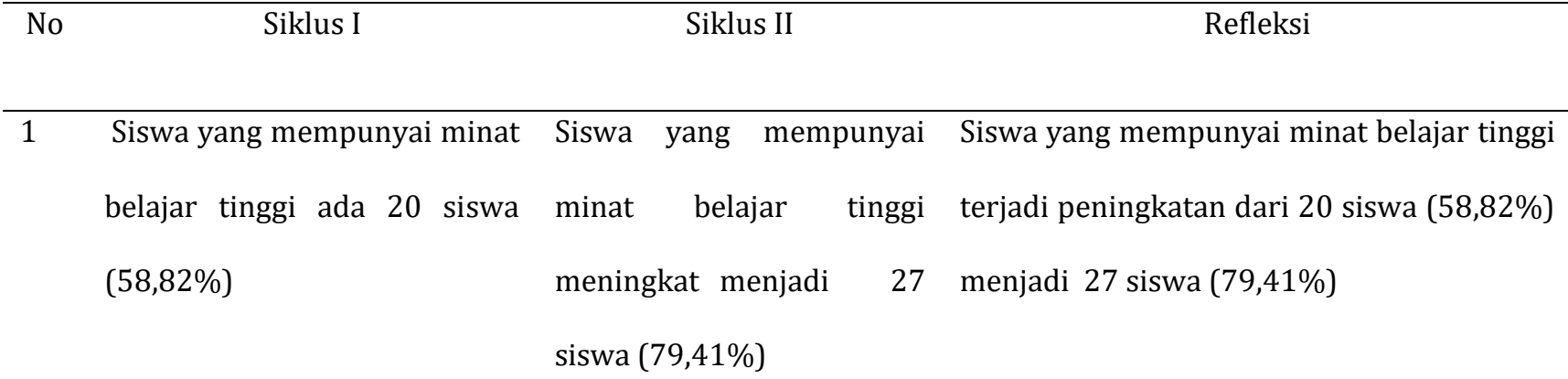

Tabel 1.1

Refleksi Minat Belajar Siklus II

Pada kondisi awal peneliti belum memanfaatkan fasilitas layanan bimbingan kelompok dalam memberikan layanan bimbingan dan konseling pada kelas VIII B di SMP NU Tegal Semester 2 Tahun Ajaran 2015/2016 sehingga siswa yang mempunyai minat belajar tinggi hanya ada 12 siswa (35,29\%). Untuk selanjutnya peneliti melaksanakan penelitian tindakan kelas pada siklus I dengan diawali mulai kegiatan sebagai berikut : (1) kegiatan perencanaan. Dalam perencanaan tindakan peneliti mendisain perencanaan dengan memanfatkan fasilitas layanan bimbingan kelompok dalam memberikan layanan bimbingan kelompok dengan mengangkat topik bahasan " bagaimana cara mengatasi minat belajar rendah" (2) pelaksanaan tindakan. Setelah perencanaan dibuat peneliti melaksanakan tindakan yang dilaksanakan pada siklus I. Adapun langkah-langkahnya sebagai berikut: (a) appersepsi yaitu membuka kegiatan yang diawali dengan salam dan do'a serta menjelaskan tujuan diadakan layanan bimbingan kelompok. (b) kegiatan inti.

Dalam kegiatan inti, setelah kelompok terbentuk, maka peneliti selaku pemimpin kelompok memberikan tugas pada anggota kelompok berupa topik bahasan "Bagaimana cara mengatasi minat belajar rendah untuk didiskusikan melalui media bimbingan kelompok. (3) pengamatan. Dalam melaksanakan kegiatan pengamatan peneliti berkolaborasi dengan teman 
Philanthropy Journal of Psychology

Vol 2 Nomor 2 (2018), 128-144

ISSN 2580-6076 (Print), ISSN 2580-8532 (Online)

sejawat untuk melaksanakan pengamatan terhadap aktivitas siswa dalam mengikuti proses layanan bimbingan kelompok. Adapun alat yang digunakan untuk pengamatan berupa lembar observasi. (4) refleksi. Setelah peneliti mendapatkan hasil pengamatan untuk selanjutnya peneliti melakukan refleksi dari hasil pelaksanaan tindakan pada siklus I. Dari hasil refleksi I terdapat beberapa kelemahan-kelemahan. Untuk selanjutnya kelemahan -kelemahan tersebut diperbaiki dengan cara membuat revisi. Selanjutnya hasil revisi dilaksanakan pada siklus II dengan langkah-langkah sebagai berikut : (1) perencanaan II, (2) pelaksanaan tindakan II, (3) pengamatan II, (4) refleksi II. Untuk selanjutnya dari hasil pengamatan pada siklus I maka didapat hasil sebagai berikut: pada kondisi awal siswa kelas VIII B di SMP NU Tegal Semester 2 Tahun Ajaran 2015/2016 siswa yang mempunyai minat belajar tinggi hanya ada 12 siswa $(35,29 \%)$ setelah peneliti melaksanakan tindakan yang dilaksanakan pada siklus I dengan memanfaatkan fasilitas layanan bimbingan kelompok dengan mengangkat topik bahasan " bagaimana cara mengatasi minat belajar rendah " didapat hasil pengamatan sebagai berikut: siswa yang mengalami kesulitan belajar terjadi perubahan yaitu siswa yang minat belajarnya tinggi meningkat menjadi 20 siswa (58,82\%), karena hasil tersebut dirasa belum mencapai indikator kinerja dalam penelitian ini selanjutnya peneliti bersama teman sejawat sebagai kolaborator memutuskan untuk mengadakan revisi, untuk selanjutnya dilaksanakan pada siklus II. Adapun hasil pengamatan pada siklus II sebagai berikut: siswa yang mempunyai minat belajar tinggi meningkat menjadi 27 siswa $(79,41 \%)$. Untuk selanjutnya dari hasil refleksi didapat hasil sebagai berikut: pada kondisi awal siswa kelas kelas VIII B di SMP NU Tegal Semester 2 Tahun Ajaran 2015/2016.

Siswa kelas VIII B di SMP NU Tegal Semester 2 Tahun Ajaran 2015/2016, pada kondisi awal yang mempunyai minat belajar tinggi ada 12 siswa (35,29\%). Sedangkan pada kondisi akhir siswa kelas VIII B di SMP NU Tegal Semester 2 Tahun Ajaran 2015/2016 meningkat menjadi 27 siswa $(79,41 \%)$. 


\begin{tabular}{|c|c|c|c|c|}
\hline No & Kondisi Awal & Siklus I & Siklus II & Refleksi Kondisi awal ke \\
\hline 1 & $\begin{array}{l}\text { Hanya sebagian kecil siswa } \\
\text { mempunyai minat belajar } \\
\text { tinggi yaitu ada } 12 \text { siswa } \\
(35,29 \%)\end{array}$ & $\begin{array}{l}\text { Sebagian siswa } \\
\text { mempunyai minat } \\
\text { belajar tinggi yaitu } \\
20 \text { siswa }(58,82 \%)\end{array}$ & $\begin{array}{l}\text { Sebagian besar } \\
\text { siswa sudah } \\
\text { mempunyai minat } \\
\text { belajar tinggi yaitu } \\
27 \text { siswa }(79,41 \%)\end{array}$ & $\begin{array}{l}\text { Siswa yang mempunyai } \\
\text { minat belajar tinggi dapat } \\
\text { meningkat dari } 12 \text { siswa } \\
(35,29 \%) \text { menjadi } 27 \text { siswa } \\
(79,41 \%)\end{array}$ \\
\hline
\end{tabular}

\section{Tabel 1.2 \\ Hasil Refleksi Minat Belajar Dari Kondisi Awal Ke Kondisi Akhir}

Melalui pemanfaatan layanan bimbingan kelompok dapat meningkatkan minat belajar bagi siswa kelas VIII B di SMP NU Tegal Semester 2 Tahun Ajaran 2015/2016 dari kondisi awal hanya sebagian kecil siswa mempunyai minat belajar tinggi yaitu ada 12 siswa (35,29\%) dan pada kondisi akhir dapat meningkat menjadi sebagian besar siswa sudah mempunyai minat belajar tinggi yaitu 27 siswa $(79,41 \%)$.

\section{Simpulan}

Variabel eksogen yaitu bimbingan kelompok dan variabel endogen minat belajar peserta didik VIII B di SMP NU Tegal Semester 2 Tahun Ajaran 2015/2016 mempunyai pengaruh yang signifikan berdasarkan data empiris. Adapun variabel yang berpengaruh dan berkontribusi secara signifikan adalah bimbingan kelompok secara signifkan berpengaruh sebesar 52,9 \% terhadap minat belajar peserta didik VIII B SMP NU Tegal Semester 2 Tahun Ajaran 2015/2016.

\section{Daftar Pustaka}

Silalahi, U. (2002). Bimbingan Kelompok, Bandung : Mandar Maju Simamora, H. (2002). Etika Bimbingan Kelompok ed III.Yogyakarta: STIE YKPN

Sugiharto, DYP. (2001). Prosedur Bimbingan Kelompok. Laporan Penelitian. Semarang: Lemhit UNNES

Sugiyo. (2008). Bimbingan dan Konseling Kelompok. Disertasi PPS

Sugiyono. (2005). Statistika Untuk Penelitian. Bandung: Alfabeta

Suparno. (2007). Minat Belajar Siswa. Semarang: PPS 
Philanthropy Journal of Psychology

Vol 2 Nomor 2 (2018), 128-144

ISSN 2580-6076 (Print), ISSN 2580-8532 (Online)

Samsudin, S. (2009), Manajemen Sumber Daya Manusia. Bandung: Pustaka Setia, Sardiman, A.M. (1990). Interaksi dan Motivasi Belajar Mengajar. Jakarta: Rajawali Pers

Scott, W.B. (1971). Relation in Management : A Beha-vioral Science Appoarch, Illinois: Homewood

Sedarmayanti. (2001). Sumber Daya manusia dan Produktivitas Kerj. Bandung: Mandar Maju. Simamora, H. (2001). Manajemen Sumber Daya Manusia. Yogyakarta: Penerbit STIE YKPN Singarimbun, M. (1995). Metodologi Penelitian Survey. Jakarta : LP3ES

Sudjana. (1996.) Metode Statistika, Bandung : Tarsito.

Sukamto. (2009). dkk Pengembangan Profesi Konselor Secara Berkesinambungan Sebagai Strategi Nasional Pendukung Sertifikasi Konselor. Yogyakarta : UNY

Suryabrata, S. (1998). Metodologi Penelitian. Jakarta: Raja Grafindo . (1983). Metodologi Penelitian. Jakarta: CV Rajawali 